\title{
Josine Junger-Tas: The Life and Works of a Compassionate Criminologist
}

\author{
Ineke Haen Marshall • Hans Boutellier
}

Published online: 12 March 2013

(C) Springer Science+Business Media Dordrecht 2013

\begin{abstract}
This article is the editorial introduction to the special issue of the European Journal of Criminal Policy and Research Compassionate Criminology: The Legacy of Josine Junger-Tas (1929-2011). The article consists of four parts and an Appendix (i.e., the bibliography of her publications). In the first section, we provide a brief overview of the highlights of her professional career of 40-plus years, including her contributions to the institutionalization of European criminology. The second section discusses how her focus on comparative criminology and policy relevance run as a red thread through her work as a criminologist. The third part centers around JungerTas's consistent concern with the responsibility of scholars and researchers to "do the right thing" and to speak out for the most vulnerable parts of the population (youth in particular). We believe that as a public criminologist avant la lettre Junger-Tas's main heritage lies in drawing the contours of what may be called evidence-based compassionate criminology. The fourth section provides a brief introduction to the seven articles in this special issue.
\end{abstract}

Keywords Compassionate criminology · Internationalization · Evidence-based ·

Public criminology

Parts of this paper draw from accounts of Josine Junger-Tas's life and contributions published in the newsletter of the European Society of Criminology, Criminology in Europe, 2011, Vol. 10, by Miklos Levay and Ineke Haen Marshall (www.escnewsletter.org.) We also thank Dirk Enzmann for his permission to include parts of the commentary he gave at the Vilnius (2011) ESC session to honor Josine Junger-Tas.

I. Haen Marshall $(\bowtie)$

Department of Sociology and School of Criminology and Criminal Justice, Northeastern University, Boston, MA 02115, USA

e-mail: i.marshall@neu.edu

H. Boutellier

Bestuurswetenschappen, Vrije Universiteit Amsterdam, 1081 HV, Amsterdam, Netherlands

email: hboutellier@verwey-jonker.nl 
"A good head and a good heart are always a formidable combination." Nelson Mandela

"Compassion is the basis of all morality." Arthur Schopenhauer

"Compassion = sympathetic consciousness of others' distress together with a desire to alleviate it." (Meriam-Webster dictionary)

\section{The Successful Career of a "Late Bloomer"}

Josine Junger-Tas was a passionate, prolific, and creative scholar who inspired many criminologists in Europe and beyond. Her contributions are recognized by the American Society of Criminology Sellin-Glueck award (1989), the American Society of Criminology Division of International Criminology Distinguished International Scholar Award (2007), and-last but definitely not least - the European Society of Criminology (ESC), European Criminology Award (2008). As the bibliography at the end of this article illustrates, she was a prolific writer, with publications written in Dutch (her native language), French, German, and English. Hers was not the typical academic career; she spent most of her working life as a civil servant and a working mother (in a time when that was not the typical routine for a mother of four daughters in The Netherlands). She saw retirement from her job with the Dutch government (in 1994) as an opportunity to finally be able to pursue her activities as a criminologist full time. Her life story, in our view, is an inspiring example of how the trajectory of one's life course does not need to be preplanned from day 1 after graduation from high school or university. As a testimony to her esteem as a criminologist, upon her death in January 2011, obituaries were published in the ESC newsletter, Criminology in Europe; the newsletter of the American Society of Criminology, The Criminologist; several Dutch professional journals, e.g., Delikt en Delinkwent, Tijdschrift voor Criminologie, as well as in a number of other European professional journals. Her passing was not only noted by the professional community of criminologists, but telling is that the three leading quality newspapers in The Netherlands paid their respects through obituaries highlighting Josine's contributions to the discourse on juvenile delinquency and crime prevention.

Josine Junger-Tas did not formally start her career as a criminologist until the age of 42 , when she received her $\mathrm{PhD}$. She wrote her dissertation on youth crime, Characteristics and Social Integration of Juvenile Delinquents, and received her $\mathrm{PhD}$ at Groningen University, The Netherlands, in 1972 under the supervision of Dutch criminologist Wouter Buikhuisen. In the early stage of her career, she worked as a researcher at the Study Centre of Juvenile Delinquency, Brussels, Belgium, but in 1975, she moved to The Netherlands, where-for about 20 years - she was associated with the Research and Documentation Center (WODC in Dutch; RDC in English) of the Dutch Ministry of Justice, honing her skills at "applied research with scientific integrity" (Junger-Tas 2005). From 1990 to 1994, as the director of the WODC, she skillfully and gracefully shepherded this government agency through difficult times, and she was instrumental in introducing the importance of evaluation studies (i.e., evidence-based policy) to the WODC and thus to The Netherlands at large.

After retiring from the WODC in 1994, she became a professor of youth criminology at the University of Lausanne, Switzerland, where she received an honorary doctorate (2000). Both before and after her retirement, she was a visiting professor at various universities (e.g., Université de Montréal, Ecole de Criminologie, Montreal, Canada; University of Stockholm, Stockholm, Sweden; University of Cambridge, Cambridge, UK), and most recently at Utrecht University, Utrecht, The Netherlands. Josine was an enthusiastic, popular, and dedicated teacher. She easily connected with undergraduate students in large lecture halls, 
but she also gave generously of her time to mentor young graduate and postgraduate scholars. Her rapport with students may have been due to her own curious mind and tireless drive to keep up with new developments. Although she liked to read mysteries when travelling, her favorite reading materials were recent international journals or books on crime, immigration, violence, family life, and politics. She taught herself SPSS (Statistical Package for the Social Sciences) at the age of 79, unwilling to leave the important task of analysis of her data to somebody else. Because of her ease in translating research findings into applied policy recommendations, Josine served on many domestic (Dutch) and international committees and advisory boards. In The Netherlands, she was a member of the Dutch National Council for the Administration of Criminal Law and Youth Protection. She was the president of the Select Committee of Experts on Juvenile Delinquency in the Council of Europe (1984-1987) and a member of the Scientific Council of the Council of Europe (1992-1996). In 2010 she travelled to Rome, Italy, to present her report titled Youth Violence and Knives, requested by the World Health Organization. A number of her many other accomplishments are presented below, starting with her contributions to the institutionalization of European criminology.

\section{Contribution to the Institutionalization of European Criminology}

Josine Junger-Tas was born in The Netherlands, spent some time as a young child in Indonesia, moved back to The Netherlands, and as a young married woman spent several years in Brussels, Belgium, before moving back to The Netherlands. There, she adopted two daughters from South Korea. Against this context, it is not too surprising that Josine JungerTas tended to look beyond national borders when it came to the discipline of criminology. In the following, we briefly highlight two important ways in which she contributed to the institutionalization of European criminology, first through her work as the founder of the European Journal of Criminal Policy and Research, and second, as one of the founders of the European Society of Criminology.

\section{Editor of the European Journal on Criminal Policy and Research}

The way Josine started the European Journal on Criminal Policy and Research is exemplary for her working style. In those days, the late 1980s, there was a positive mood regarding being European. There were many initiatives on a European level; even a newspaper was launched with that very title: The European. This weekly, billed as Europe's first national newspaper, was founded by Robert Maxwell. It lasted from 11 May 1990 until December 1998. Josine's idea was likewise to develop a forum for studying European criminology that was less dependent on the American dominance in criminology research. It was not so much a program as a kind of intuitive passion that made her organize several invitational colloquia in The Hague. It was a meaningful start of growing cooperation between scholars in Europe. Compared with earlier international exchanges between criminologists, there were two differences: an explicitly European orientation, and - in line with that - the idea to found a European criminological study community.

In addition to colloquia, Josine and RDC colleagues began thinking about a European criminological journal. The editorial policy of this journal was based on the Dutch journal, Justitiele verkenningen ( to be translated as Judicial Explorations), which was published by the RDC. This journal had a long tradition (it existed from the 1950s onward). Focusing on the disclosure of scientific literature for civil servants of the ministry, it developed into a 
policy-oriented journal with articles from (Dutch) researchers and policymakers alike. Until now, Judicial Explorations has had a theme-oriented invitational policy. It is not concerned with academic status; the editorial board invites and reviews draft articles on a chosen topic. The journal was, and still is, quite influential in the Dutch context.

That type of format also seemed to be possible in a European context, but, of course, there were some problems to overcome: it required a European editorial board, European authors, and European distribution. The first need was met by asking Martin Killias (Lausanne) and Lode Walgrave (Leuven, Belgium) to join Dutch colleagues Gerben Bruinsma (University of Twente, Enschede, The Netherlands) and Henk van de Bunt (Vrije Universiteit Amsterdam, Amsterdam, The Netherlands). It was decided that the journal, titled European Journal on Criminal Policy and Research, would be in English only (quite a decision in those days). The authors were recruited from the growing network of international relations. They were invited to contribute to a thematic issue (with almost never a refusal to accept the manuscript), and there was some copy editing by an editorial assistant (Adrienne Baars). Starting in March 1993, the journal was published four times a year, with each issue having a themerelated illustration on the cover. During the first years, the journal was published by Kugler, a small publisher of so-called "abstract journals" in criminology. After some years, the journal was transferred to Kluwer Academic Publishers, which is now part of Springer Press.

In 2004, Ernesto Savona took over as editor and - as the saying goes - the rest is history. In looking back, it may be argued that we can claim that the international colloquia at the end of the 1980s and the journal that the RDC published four times a year from 1990 onward created a breeding ground for the foundation of the European Society of Criminology.

\section{A Founder of the European Society of Criminology ${ }^{1}$}

In 2000, together with several European colleagues, Josine took the initiative to establish the European Society of Criminology. This was a crucial turning point for European criminology. Now, some 13 years later, it is hard to imagine that the ESC is of such relative recent origin. The annual meetings, the newsletter, the working groups (Josine was a member of the Working Group on Juvenile Justice) have become part and parcel of the European community of crime and deviance scholars. Josine, in her usual hands-on approach, spent many hours and days planning the very first ESC meeting in Lausanne. That first meeting, including a boat ride on the lake at night, was very successful and set a high bar for subsequent meetings.

Josine Junger-Tas was the second ESC president (presiding 2001-2002). In the words of Miklos Levay, the past ESC president, Josine "transformed the organization, operation and atmosphere of the ESC....it is clear that Josine Junger-Tas was very much aware of the requirements of development of the Society, and her efforts are detectable in the everyday life and activity of our organization" $(2011,3)$. In the very first ESC newsletter, in her first message as ESC president (Junger-Tas 2002a), she emphasized the importance of the democratic functioning of the ESC. This message also included the formation of working groups based on the decision of the executive board. The fact that there are now 14 ESC working groups proves how right she was by proposing the working groups be formed defined by subject and not by discipline. Josine regarded it as a priority to include young criminologists in the Society. It is symbolic that the Students' Paper Award, which was a predecessor of the Young Criminologist Award, was introduced during her presidency. All of

\footnotetext{
${ }^{1}$ This section is largely based on the Message from the President, Miklos Levay, published in the ESC Newsletter, Criminology in Europe, 2011/1, Vol. 10, pp 3-4 www.escnewsletter.org
} 
her actions as president demonstrated her dedication to form a Society that is not only a forum to present research findings but also produces to findings through the collaborative research of members.

Josine regarded the ESC as a catalyst of the development of European criminology independent from American traditions. Her third presidential message, titled My Hopes for the Future of Criminology in Europe, discusses the most important steps to achieve this goal. It mentions as a priority that the ESC methodically supports empirical research. Taking the multidisciplinary nature of criminology into consideration, she thought that the enrichment of university curricula is extremely important. She called for changes in four areas of European criminology curricula: (i) there should be more room for quantitative and qualitative research methods at the expense of legal courses; (ii) more attention should be given to get to know the actual working methods of the police and criminal justice; (iii) it should be ensured that students are aware of how their research findings are used and misused by certain authorities; (iv) western-European universities should furthermore be obligated to offer special courses for students form Central and Eastern Europe (Junger-Tas 2002b). ${ }^{2}$

Importantly, she envisioned the development of the ESC based on European principles, namely: “...those of the Enlightenment — emphasizing reason, empiricism, and human rightsand those of social care and support for the losers in our society." ${ }^{3}$ These words completely capture Josine's approach to criminology (as will be discussed in the later sections on compassionate criminology). Attesting to the importance of the ESC in Josine's career, in her speech at the 2009 Annual Meeting of the ESC in Ljubljana, Slovenia, given on the occasion of winning the European Criminology Award, she called the award "the top prize of my career" (Junger-Tas 2009)

\section{A Policy-oriented Criminologist with an International Perspective}

\section{One of the Early Believers in Comparative Work}

Almost from the very beginnings of her career, Josine published in Dutch, French, Belgian, and German outlets, often explaining how the Dutch system of (juvenile) justice fit (i.e., is different or similar to other nations) within an international context (e.g., Junger-Tas (1980c, $1984 a, c)$. From the onset, she was interested in empirical research focusing on youth (see her dissertation: Characteristics and Social Integration of Juvenile Delinquents). [Later, when she was director at the WODC, she also instituted at the WODC the first self-reported delinquency survey in The Netherlands (which by now has become a regular feature).] She soon combined her empirical orientation with the added value of a comparative or crossnational perspective. Although it is hard to conclude retrospectively who or what shaped her interests and vision, she herself often identified the influence of Malcolm Klein, an American researcher most known for his work on self-reported surveys of youth delinquency and gangs, as an inspiring colleague through his combination of self-report methodology with cross-national research. In 1988, Klein cohosted a workshop in The Netherlands, sponsored by the North Atlantic Treaty Organization (NATO), titled "Self-Report Methodology in Criminological Research," in which some 40 scholars participated (Klein 1989). This workshop was cosponsored by the WODC, at the time headed by Jan van Dijk. The participants

\footnotetext{
${ }^{2}$ Regarding this last point, it should be mentioned that during Josine's presidency, a special fellowship program was set up by the board to enable researchers from central and eastern Europe to participate at the annual meetings of the ESC.

3 ibid. 15 .
} 
represented 15 nations, and the focus was on a discussion of the possibility to develop an internationally standardized self-report survey to measure delinquency. This NATO workshop became the launching pad for the International Self-Report Study of Delinquency (ISRD), sponsored initially by the WODC. In Josine's own words: "the ISRD was created in 1990 when a number of researchers, representing 13-mainly Europeancountries, came together to decide on conducting.... a study and to develop a common methodology" (Junger-Tas. et al. 2003, 4). A working group of researchers from six government centers and seven universities developed a common questionnaire and a research protocol aimed at achieving a comparable way of measuring self-reported delinquency among youth in participating countries. In 1994, a first book was published, containing the reports of the 13 participating countries (Junger-Tas et al. 1994), followed in 2003 with a book reporting on the analysis of the integrated data base (Junger-Tas. et al. 2003).

The first ISRD (ISRD-1) was reimagined later as the pilot for the second study (ISRD-2), a much expanded project in which more than 30 countries collaborated. Data for ISRD-2 were collected between 2005 and 2007. Several publications have followed (Junger-Tas et al. 2010; Enzmann et al. 2010), the most recent one being The Many Faces of Youth Crime: Comparing and Contrasting Theoretical Perspectives on Youth Crime, which was published after her death. The success of ISRD-2 inspired Josine and other colleagues to continue to build on the foundations and to prepare a third ISRD study, using a partly modified questionnaire allowing the testing of theories such as Institutional Anomie Theory, Procedural Justice Theory, and Situational Action Theory. Sadly, Josine was unable to witness to beginning of the field work for ISRD-3, which took place in September 2012. Josine's leadership in the ISRD project reflected her typical vision of international collaboration: always trying to work from the bottom up (i.e., all participants should have input), ensuring that everybody has a true stake in the project. Here, as was true for her vision of the ESC, she truly believed in a democratic approach to collaboration.

The ISRD combined Josine's enthusiasm for empirical research on youth, the valueadded contributions of comparative work, with the methodology of self-report, on which she was considered an international expert (see Junger-Tas. and Haen-Marshall 1999). However, there were many other comparative or international research and academic projects in which Josine participated. As far back as 1983, she contributed a chapter on Dutch criminology to the well-known American publication Crime and Justice, edited by Tonry and Morris (1983c). Interestingly, many years later, she coauthored a follow-up article on the very same topic in the same publication (Junger-Tas and Junger 2007). In addition, she coauthored several important comparative volumes on juvenile justice and juvenile delinquency. Most recently, for example, The Handbook of International Juvenile Justice, together with American criminologist Scott Decker (2006); and Reforming Juvenile Justice, with her German colleague Frieder Dünkel (2009).

\section{Criminology Must be Relevant to Policy}

An outstanding scholar who enjoyed academic discourse and faithfully attended academic conferences in Europe and in the US, Josine was anything but an ivory tower intellectual. That was true for her work at the WODC which demanded per definition a policyorientation, but it also held true for her other empirical endeavors, such as the ISRD. She was committed to the importance of theoretical grounding of research (social bonding theory, with its focus on the family was her favorite), but she combined this with a strong 
belief that all research needs to have a policy-implication. As a quote from her European Criminology Award address in 2009 shows:

As I see it, the social sciences, including criminology, have a second fundamental mission besides realization of their ambition to conduct fundamental research and advance scientific knowledge. That mission is to make a contribution, however small, to achieving a somewhat fairer, more humane, and more rational society. It is absolutely necessary in contemporary society that researchers attempt to inform the development of policy. The use of reason - manifested in research - will lead to a better, clearer relationship between the ends and means of policy (Junger-Tas 2009).

Josine was well aware of the dangers inherent in the collaboration with politicians, politics, and authorities. In her article in Justitiële verkenningen (1990a), she lists the following dangers: ${ }^{4}$

- Governmental agencies determine research priorities and try to fund research only on those practical problems they want to solve (e.g., research on drugs, crime \& terrorism), thus keeping researchers away from more urgent problems.

- Researchers who interact closely with authorities run the risk of losing critical distance by identifying themselves too closely with the government's political problems and priorities.

- Some researchers react to the need of political agencies for easy communicable results and to their wish not to be confronted with the failure of policy measures by purging their own reports from meaningful content, resulting in meaningless recommendations.

- Research may be misused by politicians as a pretext for delaying the solution of problems that involve difficult political decisions.

As Dirk Enzmann concluded in his presentation at the Vilnius ESC conference commemorating Josine (2011), ${ }^{5}$ she was able to combine a strong commitment to policy-relevant research, with an explicit and strong grounding in a moral belief that it is one's duty to do what is right. Although Josine has written about many topics (e.g., police, prisons, crime trends, survey methodology, human rights, evaluation programs, social welfare, family policy), her passion was first and foremost for youth and youth problems. She argued that we need to invest in prevention, rather than treatment, and that we need to have theoretical insights that may guide our prevention efforts; so was her belief. In the categorization made by the sociologist Burawoy (2005), Josine was able to integrate professional criminology (i.e., she believed in the proper use of method and theory), policy criminology (evidencebased and applied sociology), and public criminology (one needs to have a civic engagement).

\section{A Compassionate Criminologist}

Indeed, in the parlance of today, Josine Junger-Tas could be viewed as a public criminologist. She was not afraid to speak her mind. As her obituary in the NRC (the leading Dutch

\footnotetext{
${ }^{4}$ These points are taken from the paper presented by Dirk Enzmann (Points of View and the Value of Values in Scientific Criminology) in the memorial session on Josine Junger-Tas's work at the ESC conference in Vilnius, 2011.

5 ibid.
} 
newspaper) states: "Professor Junger-Tas was very concerned with the fate of children and youth with problems... and she was very bothered by how Dutch police and social welfare agencies over the last several years started to control children and youth." The NRC article explains how Josine characterized the collection of DNA materials of minors as "nonsense and objectionable"; the removal of children from their homes because the parents are not up to their task as "damaging"; and the systematic compiling of records of all children (with their risk factors, or parental unemployment, or attention deficit/hyperactivity disorder) as "counter-productive." She was a fervent and compassionate believer in prevention rather than punishment, and she often spoke out publicly against the more repressive and hard-line youth policies that emerged in The Netherlands over the last decade. In radio and television interviews as well as in printed media, she questioned the "hype" about alleged rising crime rates, and she never hesitated to express her indignation about the increasing repressive nature of youth policy.

In the special session organized to pay tribute to Josine at the 2011 Vilnius ESC conference, Enzmann, in his talk "Points of view and the value of values in scientific criminology," documented how Josine acted as a scientific researcher striving for objectivity while at the same time adhering to humanistic convictions. In his view, Josine taught us the necessity of values to keep up one's course in times of paradigm shifts toward punitivity; how adherence to basic values can coexist with the pursuit of "value-free" research and objectivity in science - a necessity if we want criminology to have an impact on criminal policy. In a discipline in which there is increasing tension between the demand and call for accountability and social responsibility, Josine's view on the role of criminologists may be best captured by the concept of compassionate criminology.

Compassionate criminology does not only mean that one speaks one's mind (publicly), but also that one has true empathy for the suffering of others. Although we are usually reluctant to refer to Wikipedia as a reliable reference source, in this particular instance, we gladly accept that "Compassion is a cornerstone of greater social interconnection and humanism" (en.wikipedia.org/wiki/Compassion). Compassionate criminology should never be confused with moralizing criminology, an approach that Josine detested outright. "Compassion is the basis of all morality," said the nineteenth century German philosopher Arthur Schopenhauer. Unlike Schopenhauer, Josine believed in the role of reason and science to create a better future, but she combined this with a firm grounding in the need for empathy for the most vulnerable in society. And that is what compassionate criminology is all about.

\section{Introduction to the Articles in this Issue}

The articles in this special issue have been selected because they represent, in one way or another, key aspects of Josine Junger-Tas's contributions to the discipline. We believe that as a public criminologist, Junger-Tas's main heritage lies in drawing the contours of what may be called evidence-based compassionate criminology. Considering Josine's extensive network of international colleagues and friends familiar with her work, the issue easily could have been double or triple its size. In order to provide a more complete overview of her work, we therefore included, at the end of this introduction, an overview of (most) of Josine's publications. This bibliography may be missing a number of papers, as Josine notoriously was rather nonchalant when it came to keeping track of all the work she produced. 
The first article, by Michael Tonry, provides a perfect opening for this special issue. He discusses how Josine's distinctive form of compassionate criminology is a point of view, a way of looking at the world, "predicated on the belief that individual human beings matter, and always matter, and that the only ethical way to think about policies and practices is in terms of their implications for individuals and the lives that they have led or potentially can lead." Tonry uses Josine's contributions to Crime and Justice: A Review of Research to show that Josine's compassion "reveals itself in the subjects of her work, in her sympathies for the distressed, and in her efforts always to place things in rich human contexts of time, place, and history."

The second article, by Michael Gottfredson, on the role of basic theory in thinking about crime prevention, speaks to Josine's firm belief in the connection between basic theory and delinquency prevention policies. All who are familiar with Josine's empirical work, as well as her policy suggestions with regard to youth, know that the different variants of social control theory (with their focus on the importance of the family) played a crucial role. As Gottfredson argues convincingly, recent research appears consistent with control-theory expectations and with Josine's view for a role for basic science for juvenile policy.

In a third article, Majone Steketee and her colleagues compare the implementation and adoption of Communities that Care (CtC), a community-based prevention system to prevent adolescent drug use and delinquency in The Netherlands and the US. Consistent with her belief in evidence-based policy and her international perspective, Josine introduced the CtC prevention system in The Netherlands in 1999. This article demonstrates both contributions and challenges of the international transfer of crime policies.

The fourth article, by Josine's daughter, Marianne, and her colleagues, approaches the role of the family in crime prevention from the perspective of the intergenerational transmission of delinquency. They analyze the police records of the family members of a cohort of Dutch individuals and conclude that arrests of family members constitute a major risk factor for poor developmental outcomes, such as criminal behavior. Marianne Junger and colleagues conclude that an early, evidence-based intervention strategies prevent these children from repeating the mistakes of their predecessors, based on these and others' findings that families evidencing criminal involvement often yield children at-risk of criminality.

The last three articles (Farrington et al., Gatti at al., Kapardis) in this special issue all speak to Josine Junger-Tas's enthusiasm for the method of self-report surveys as a credible alternative to the use of official crime records. Josine was a pragmatist in many ways, but she did insist that it was important to conduct self-report surveys in the most careful ways possible, including testing the validity and reliability of this method. The congruence between self-reported offending with official records of convictions is the focus of David Farrington and colleagues' contribution in this issue. Based on analysis of data from the Cambridge Study in Delinquent Development, where over 400 London males have been followed up from age 8 to age 48 in face-to-face interviews and up to age 56 in criminal records, they conclude that convicted males self-reported 25 offenses per conviction on average, and therefore, the "scaling-up factor" from convictions to self-reported offenses is very important, especially in evaluating the effectiveness of intervention programs. The articles by Gatti and colleagues and Kapardis are based on data collected as part of the ISRD-2. The Gatti article focuses on data collected among 25 European nations to determine the link between alcohol consumption and delinquency, as well as the role of belonging to a youth gang. Recognizing the complexity of social reality, they conclude that the associations between alcohol use and delinquency are reciprocal rather than one-directional: Whereas 
alcohol use constitutes a risk factor for criminal behavior, involvement in delinquency increase the risk of alcohol consumption and, especially, alcohol abuse. This analysis implies clear implications for prevention at the level of national and local alcohol policy. Concern with delinquency prevention is also part of the contribution by Andreas Kapardis in his paper in this issue that focuses on Cyprus, as well as the ISRD-2 results on the (capitals of) the Czech Republic, Estonia, Lithuania, Poland, and Slovenia. ${ }^{6}$ Kapardis writes in his introduction that Josine was the "catalyst which made it all possible." That is, apart from the substantive and methodological contributions that Josine has made to the ISRD project, it is evident that she had a crucial role in getting this complex international collaborative project off the ground. We think it fitting to conclude with Kapardis's words: " inspirational, she infused us with enthusiasm about the project and dealt with any disagreements in a very constructive way. A very caring social scientist and a committed reformer who led her team by example. In a nutshell, a very charismatic person and scholar I am grateful I had the opportunity to work with." Indeed, a good head and a good heart are always a formidable combination.

\section{References}

Junger-Tas J. (2002a). Message from the President. Report from Lausanne. ESC Newsletter Criminology in Europe, 1(1):1, 8-9.

Junger-Tas, J. (2002b). My hopes for the future of Criminology in Europe, ESC Newsletter Criminology in Europe, 1(3):2, 15.

Junger-Tas J. (2009). Challenges to Criminology in the 21st century. ESC Newsletter Criminology in Europe, 8(3):13-16. [Online: http://www.esc-eurocrim.org/newsletter/Nov09ESCnewsletter.pdf]

Klein, Malcolm W. (ed) (1989). Cross-national research in self-reported crime and delinquency. Kluwer, Alphen aan den Rijn.

Burawoy, M. (2005). For public sociology. American Sociological Review, 70(1):4-28.

\section{A Selection from Josine Junger-Tas's Publications}

Enzmann, D., Marshall, I. H., Killias, M., Junger-Tas, J., Steketee, M., \& Gruszczynska, B. (2010). Selfreported delinquency in Europe and beyond: first results of the second ISRD (International Self-Report Study) in the context of police and victimization data. European Journal of Criminology, 7(2), 159-183. Junger-Tas, J. (1976a). Autodiefstal (Carjacking). The Hague: WODC - Ministry of Justice.

Junger-Tas, J. (1976b). Verborgen jeugddelinkwentie en gerechtelijke selektie: Een onderzoek in een stadsmilieu (Hidden juvenile delinquency and judicial selection; a study in a urban environment). Brussel: Studiecentrum voor Jeugdmisdadigheid.

Junger-Tas, J. (1979). Juvenile court structures; problems and dilemmas. The Hague: Research and Documentation Centre - Ministery of Justice.

Junger-Tas, J. (1980a). Strukturen des Jugendgerichts: Probleme und dilemmas (Structures of the juvenile court), Zentralblatt für Jugendrecht und Jugenswohlfahrt, 67, August.

Junger-Tas, J. (1980b). Justitiële kinderbescherming en hulpverlening (Judicial childprotection and assistance), Justitiële Verkenningen, 6(3).

Junger-Tas, J. (1980c). The case of The Netherlands. In V. Lorne Stewart (Ed.), Justice and troubled children around the world. New York: New York University Press.

\footnotetext{
${ }^{6}$ These 6 countries (which joined the European Union in 2004) received support from a Daphne grant to participate in the ISRD-2. This grant was written and administered by the Verwey-Jonker Institute in Utrecht, The Netherlands.
} 
Junger-Tas, J. (1981a). Politiecontacten van minderjarigen en justitiële afdoening (Police contacts of minors and judicial settlement). The Hague: Staatsuitgeverij.

Junger-Tas, J. (1981b). Veranderingen in de residentiële en ambulante zorg voor kinderen (Changes in residential and ambulatory care for children). Jeugdbescherming en Onderzoek, special issue, 37 p. The Hague: CWOK.

Junger-Tas, J. (1981c). Onvoorziene gevolgen van veranderingen binnen de kinderbescherming (Unforeseen consequences within childprotection), Justitiële Verkenningen, 7(8).

Junger-Tas, J. (1981d). Community service en dienstverlening: een kritische beschouwing (Community service and service provision), Delikt en Delinkwent, 11(1).

Junger-Tas, J. (1981e) Probation research in The Netherlands, in: Perspektiven und Probleme Kriminologischer Forschung, Hannover, Kriminolog. Forschungsinst. Nieder-Sachsen.

Junger-Tas, J. (1982). Uithuisplaatsing van Kinderen (Outplacement of children). Jeugdbescherming en Onderzoek, special issue, $82 \mathrm{p}$. The Hague: CWOK.

Junger-Tas, J. (1983a). Minority juveniles and the 'Dutch police'. The Hague: Research and Documentation Center, Ministry of Justice.

Junger-Tas, J. (1983b). Kinderrecht en kinderwelzijn in historisch perspectief (Childer's rights and welfare in a historical perspective) (pre-advies Vereniging voor Familie- en Jeugdrecht), Tijdschrift voor Familie- en Jeugdrecht, 5(7/8).

Junger-Tas, J. (1983c). Intermediate treatment - een nieuwe vorm van ambulante hulpverlening (Intermediate treatment - a new form of ambulatory assistance), Proces, no.4.

Junger-Tas, J. (1983d) Some consequences of changes in the processing of juveniles through the child protection system in The Netherlands, in: Youth Crime, Social Control and Prevention. Wuppertal University: BRD.

Junger-Tas, J. (1983e). Criminological research in The Netherlands. In M. Tonry \& N. Morris (Eds.), Crime and justice, vol. 5. Chicago: University of Chicago Press.

Junger-Tas, J. (1984a). Child protection and juvenile justice in Holland. In M. W. Klein (Ed.), Western systems of Juvenile justice. Beverly Hills: Sage Publ.

Junger-Tas, J. (1984b). Tehuis of Gezin: Waar kiezen we voor? (Shelter or Family: what do we choose?), in: T. Weterings (ed.) Opgroeien in een Pleeggezin. Loghum: Slaterus.

Junger-Tas, J. (1984c). Recent Trends in Juvenile Delinquency and Reactions of the Juvenile Justice System, Report for the Council of Europe (Select Committee of Experts on Juvenile Delinquency).

Junger-Tas, J. (1985a). Allochtone Jongeren in Nederland (Immigrant youth in The Netherlands), Justitiële Verkenningen, 11(3).

Junger-Tas, J. (1985b) De Theorie van sociale controle of sociale binding (The theory of social control or social bonding). Tijdschrift voor Criminologie, 27, Nov/Dec.

Junger-Tas, J. (1985c) Expériences de sanctions alternatives pour jeunes aux Pays-Bas (Experiences of sanction alternatives for the youth in The Netherlands). Mesures Réparatrices, Belgique: Namur.

Junger-Tas. (1985d). Le cas des Pays-Bas: La Tolérance et la Bienveillance (The case of The Netherlands: tolerance or benevolence). In R. E. Tremblay, A. M. Gavard, \& R. Jost (Eds.), Le traittement des adolescents délinquants. Paris: Editions Fleurus.

Junger-Tas, J. (1986a). Taak en functie van de jeugdpolitie (Role and function of the juvenile police). Justitiële Verkenningen, 12(5).

Junger-Tas, J. (1986b). Het standjesbeleid van politie en OM (Police and judicial scolding policy). Trema Tijdschrift voor de Rechterlijke Macht,. IX(2).

Junger-Tas, J. (1987). School en criminaliteit (School and crime). Justitiële Verkenningen, 13(4).

Junger-Tas, J. (1988a). Social crime prevention in Holland, Research Bulletin of the Home office RPU, no. 24.

Junger-Tas, J. (1988b). Veranderingen in het gezin en reacties op delinquent gedrag (Changes within the family and reactions to delinquent behavior). Justitiële Verkenningen, 14(8).

Junger-Tas, J. (1989). Self-report delinquency research in Holland with a Perspective on International Comparison. In M. W. Klein (Ed.), Cross-national research in self-reported crime and delinquency. Dordrecht: Kluwer.

Junger-Tas, J. (1990a). Normvervaging of normverschuiving (Moral blurring or moral shift). Justitiële Verkenningen, 16(1).

Junger-Tas, J. (1990b). Alternatieve sancties in de verenigde staten (Alternative sanctions in the United States). Delikt en Delinkwent, 20, June.

Junger-Tas, J. (1990c). Prevention of Delinquency, Juvenile Justice and the Protection of the Young: Policy approaches and Directions, Report for the United Nations in preparation of the VIIIth Congress on the Prevention of Crime and the Treatment of Offenders.

Junger-Tas, J. (1991a). Vrijwilligheid en dwang in behandeling en hulpverlening (Voluntariness and coercion in the context of treatment and assistance). Justitële Verkenningen, 17(2).

Junger-Tas, J. (1991b). The Young Adult Offender: some Quantitative and Qualitative Data, Report for the Council of Europe, Criminological Conference. 
Junger-Tas, J. (1992a). Changes in the family and their impact on delinquency, European Journal on Criminal Policy and Research, 1(1).

Junger-Tas, J. (1992b) Juvenile Delinquency in The Netherlands - trends and perspectives, International Journal of comparative and Applied Criminal Justice, $16(1 \& 2)$.

Junger-Tas, J. (1993a). Policy evaluation research in criminal justice, studies on crime and crime prevention, vol. 2. Stockholm: National Council of Crime Prevention.

Junger-Tas, J. (1993b). Alternatives to prison sentences - experiences and developments. Amsterdam: Kugler publ.

Junger-Tas, J. (1994a). Vernieuwing en behoudzucht in het strafrecht (Renewal and conservatism in criminal law). Justitiële Verkenningen, 20(2).

Junger-Tas, J. (1994b). Alternative sanctions: myth and reality, European Journal on Criminal Policy and Research, 2(1).

Junger-Tas, J. (1995a). Preventie van criminaliteit in theorie en praktijk (Prevention of crime in theory and practice), Sociale Informatie, $n r .3$.

Junger-Tas, J. (1995b). Sentencing in The Netherlands - context and policy, Federal Sentencing Reporter, 7(6).

Junger-Tas, J. (1995c). Elinquency similar in Western countries, Overcrowded Times, 7(1).

Junger-Tas, J. (1995d). Het raadsel van de Vrouwencriminaliteit (The puzzle of female crime), in: NemesisEssays, 20-44.

Junger-Tas, J. (1996a). Youth and violence in Europe, Studies on Crime and Crime Prevention, 5(1).

Junger-Tas, J. (1996b). Jeugd en Gezin I - preventie vanuit een justitieel perspectief (Youth and family IPrevention from a judicial perspective). The Hague: Ministry of Justice, SDU.

Junger-Tas, J. (1997a). Ethnic minorities and criminal justice in The Netherlands, In: M. Tonry (ed.) Crime and Justice - an Annual Review, vol. 21, University of Chicago Press.

Junger-Tas, J. (1997b). Juvenile delinquency and juvenile justice in The Netherlands. In J. Winterdyk (Ed.), Juvenile justice systems - international perspectives. Toronto: Canadian Scholars'Press.

Junger-Tas, J. (1997c). Gezin, jeugd en preventie (Family, youth and prevention). Nederl. Tijdschr. voor Opvoeding. Vorming en Onderwijs, jrg. 13(5).

Junger-Tas, J. (1997d). Jeugd en Gezin II - naar een effectief preventiebeleid (Youth and family - towards an effective prevention policy). The Hague: Ministry of Justice.

Junger-Tas, J. (1998a). The Netherlands. In J. Mehlbye \& L. Walgrave (Eds.), Confronting youth in Europe. Copenhagen: AKF Forlaget.

Junger-Tas, J. (1998b). Een justitieel preventiebeleid (Judicial prevention policy), in: W. Koops \& W. Slot (red.) Van lastig tot misdadig, Houten/Diegem Bohn Stafleu Van Loghum.

Junger-Tas, J. (1998c). Predictie van criminaliteit en preventief ingrijpen (Prediction of crime and preventive intervention). Comenius, $18(1)$.

Junger-Tas, J. (1998d). Recent trends in sentencing policies in The Netherlands. European Journal on Criminal Policy and Research, 6(4), 479-505.

Junger-Tas, J. (1999a). Nieuwe ontwikkelingen in de aanpak van jeugdigen met onaangepast gedrag: Voer voor criminologen en psychologen? (New developments in tackling anti-social behavior among youth: Food for criminologists and psychologists?), in: A. Collot d'Escury Koenigs, A.v.d. Linden \& T. Snaterse (eds.) Van Preventie tot Straf, Lisse: Swets \& Zeitlinger, publishers.

Junger-Tas, J. (1999b) The Prevention of Serious and Persistent Juvenile Crime, report for the United Nations/ Council of Europe, Workshop in Sarajewo, Bosnia.

Junger-Tas, J. (1999c). Diploma's en Goed Gedrag - de Maatschappelijke flFunctie van het Onderwijs (Diplomas and good behavior - Prevention of anti-social behavior through education.). The Hague: Ministry of Justice.

Junger-Tas, J. (2001a). Recent trends in sentencing policies in The Netherlands. In H. J. Albrecht \& A. van Kalmthout (Eds.), Community sanctions and measures in Europe and North America (pp. 349-379). Freiburg: Max Planck Institut.

Junger-Tas, J. (2001b). The juvenile justice system - past and present trends in western society. In T. H. Höynck, R. Soisson, W. Trede, \& H.-D. Will (Eds.), Youth care - youth punishment (pp. 79-109). Frankfurt: IgfH-Eigenverlag.

Junger-Tas, J. (2004a). Social welfare and juvenile justice in The Netherlands, in: Crime and Justice - a review of research- M. Tonry (ed.), vol.31, 293-348.

Junger-Tas, J. (2004b). Implementatie en evaluatie van preventieprogramma's (Implementation and evaluation of prevention programs). Proces, tijdschrift voor Strafrechtspleging, 83(1), 2-10.

Junger-Tas, J. (2004c). Internationale ontwikkelingen in het Jeugdstrafrecht (International developments in juvenile criminal law), in: K. Blankman \& M. Bruning (red.) Meesterlijk Groot voor de Kleintjes, Kluwer, 195-211.

Junger-Tas, J. (2005). The scientific integrity of applied research, in European Journal on Criminal Policy and Research, 11(2). 
Junger-Tas, J. (2006). The respect of prisoners' rights in an international context, European Journal on Criminal Policy and Research, 12(2).

Junger-Tas, J. (2007). De behandeling van jongeren in justitiële inrichtingen (The treatment of youths in correctional institutions). Delikt en Delinkwent, 37(10), 1001-1020.

Junger-Tas, J. (2010a). The significance of the International Self-report Delinquency Study (ISRD). European Journal on Criminal Policy and Research, 16(2), 71-87.

Junger-Tas, J. (2010b) Youth Violence and Knives, report requested by the World Health Organization.

Junger-Tas, J., \& Block, R. L. (Eds.). (1988). Juvenile delinquency in The Netherlands. Amstelveen: Kugler.

Junger-Tas, J. \& Bruinsma, G., (eds.) (1992) Quantitative criminology in The Netherlands, Journal of Quantitative Criminology -special issue-, 8(1).

Junger-Tas, J., \& Decker, S. (2006). Handbook of international juvenile justice. New York: Springer

Junger-Tas, J., \& Dünkel, F. (Eds.). (2009). Reforming juvenile justice. New York: Springer.

Junger-Tas, J., \& Feder, L. (2008). Preventie van agressie (Prevention of aggression). In I. Weijers (Ed.), Justitiële interventies voor jeugdige daders. The Hague: Boom Juridische uitgeverij.

Junger-Tas, J. \& Haen-Marshall, I., (1999) The self-report methodology in crime research -strengths and weaknesses, In: M. Tonry (ed.) Crime and Justice - a Review of research, vol 25, p. 291-367.

Junger-Tas, J., \& Holten-Vriesema, J. S. E. (1979). Relatie tussen de primaire politie-opleiding en de politiepraktijk: Eindrapport (Relationship between the police training and police practice; final report). The Hague: Staatsuitgeverij.

Junger-Tas, J. \& M. M. J Aalberts, M. M. J., Boutellier, J. C. J (1995). Rechtsverzorging en wetenschap: een plaatsbepaling van het WODC bij het afscheid van J. Junger-Tas (Law and science: a contextual evaluation of the RDC at the occassion of the departure of J. Junger-Tas). Arnhem: Gouda Quint.

Junger-Tas, J. \& Junger, M. (2007). The Dutch Criminological Enterprise, In: M. Tonry \& C. Bijleveld (eds.) Crime and Justice in The Netherlands, 115-163.

Junger-Tas, J., \& Kester, J. G. C. (1994). Criminaliteit en strafrechtelijke reactie: Ontwikkelingen en samenhangen (Crime and criminal response: trends and developments). Arnhem: Gouda Quint.

Junger-Tas, J., \& Kruissink, M. (1987). De ontwikkeling van de jeugdcriminaliteit (The development of juvenile delinquency), $n r$. 79. The Hague: WODC - Ministerie van Justitie, publ.

Junger-Tas, J., \& Schalken, T. M. (1983). Recht en welzijn in het jeugdstrafrecht: Preadviezen (Law and welfare in the juvenile justice system: preliminary reports). Zwolle: W.E.J. Tjeenk Willink.

Junger-Tas, J. \& Terlouw, G. J. (1991) Het Nederlandse publiek en het criminaliteitsprobleem (The Dutch public and the crime problem). Delikt en Delinkwent, March and April.

Junger-Tas, J., \& Tigges, L. C. M. (1982). Justitieel maatschappelijk werk: Heden en toekomst (Judicial social work: present and future). Delikt en Delinkwent, 12(2).

Junger-Tas, J., \& van de Laan, P. (1995). Jeugdcriminaliteit (Juvenile Crime), 1980-1992. The Hague: WODC - Ministry of Justice.

Junger-Tas, J., \& van der Zee-Nefkens, A. A. (1978). Publiek en politie: ervaringen, houdingen en wensen: Een onderzoek onder de Nederlandse bevolking (Public and police: Experiences, attitudes and demands: A survey of the Dutch population). The Hague: WODC - Ministry of Justice.

Junger-Tas,J. \& Zee-Nefkens van der, A. A., (1978) Van opleiding naar praktijk: een evaluatie door aspiranten en jonge politieambtenaren: een onderzoek ingesteld door de ministeries van Justitie en Binnenlandse Zaken en de Stichting ITOBA (From training to practice: an evaluation by aspirants and young police officers: an investigation by the Ministeries of Justice and the Ministerie of the Interior and the ITOBA Foundation). The Hague: WODC - Ministerie van Justitie.

Junger-Tas, J., \& van der Zee-Nefkens, A. A. (1980). Preventieve hechtenis minderjarigen (The preventive detention of minors). The Hague: Staatsuitgeverij.

Junger-Tas, J., \& van Kesteren, J. (1999). Bullying and delinquency in a Dutch schoolpopulation. The Hague: Kugler Publications.

Junger-Tas, J., Junger, M., Barendse-Hoornweg, E., \& Sampiemon, M. (1983). Jeugddelinquentie - achtergronden en justitële reactie (Juvenile delinquency - background and judicial response), nr.42. The Hague: WODC - Ministerie van Justitie, The Hague, publ.

Junger-Tas, J., Junger, M., \& Barendse-Hoornweg, E. (1985). Jeugddelinquentie - de Invloed van Justitieel Ingrijpen (Juvenile delinquency - the impact of judicial intervention), $n r$ 63. The Hague: WODC Ministerie van Justitie, publ.

Junger-Tas, J. \& Kruissink, M. Ontwikkeling van de Jeugdcriminaliteit II (The development of juvenile crime II). Arnhem: Gouda Quint.

Junger-Tas, J. \& Rutting, A., Wilzing, J., (Eds.) (1988). Crime Control in Local Communities in Europe. Lochum: van den Brink, nrs. 5a \& 5b.

Junger-Tas, J., Boendermaker, L., \& van der Laan, P. H. (1991). The future of the juvenile justice system (L'avenir du système penal des mineurs). Leuven: Acco. 
Junger-Tas, J., Sagel-Grande, H. I., \& Buikhuisen, W. (1991). Criminology in the 21st century: A collection of essays presented to professor Wouter Buikhuisen. Apeldoorn: Garant.

Junger-Tas, J., Malcolm, M., Klein, W., \& Zhang, X. (1992). Problems and dilemmas in comparative selfreport delinquency research. In D. P. Farrington \& S. Walklate (Eds.), Offenders and victims: Theory and policy. London: British Society of Criminology.

Junger-Tas, J., Kruissink, M., \& van de Laan, P. (1992). Ontwikkeling van de jeugdcriminaliteit en de justitiële kinderbescherming, 1980-1990. Arnhem: Gouda Quint.

Junger-Tas, J., Terlouw, G. J., \& Klein, M. W. (Eds.). (1994). Delinquent behavior among young people in the Western World - first results of the international self-report delinquency study, Publ. Amsterdam: Kugler.

Junger-Tas, J., Smith, P. K., Morita, Y., Olweus, D., Catalano, R., \& Slee, P. (1999). The nature of school bullying - a cross-national perspective. London: Routledge.

Junger-Tas, J., Cruyff, M. J. L. F., Looijen Jansen van de, P. M. \& Reelick, F. (2003). Etnische minderheden en het Belang van Binding: een onderzoek naar antisociaal gedrag van jongeren (Etnic minorities and the importance of social bonding: a study of anti-social behavior among youths). SDU/Vermande.

Junger-Tas, J. \& Marshall, I. H., Ribeaud, D. (2003). Delinquency in an International Perspective - The International Self-Report Delinquency Study, Criminal Justice Press/Kugler publications.

Junger-Tas, J., Ribeaud, D., \& Cruyff, M. J. L. F. (2004). Juvenile delinquency and gender. European Journal of Criminology, 1(3), 333-377.

Junger-Tas, J. \& Steketee, M., Moll, M. (2008). Achtergronden van Jeugddelinquentie en Middelengebruik (Background of juvenile delinquency and substance use), Verwey-Jonker Instituut.

Junger-Tas, J. \& Marshall, I. H., Enzmann, D., Killias, M., Steketee, M., Gruszczynska, B. (2010). Juvenile Delinquency in Europe and Beyond - Results of the Second International Self-Report Study, New York: Springer.

Junger-Tas, J., Haen Marshall, I., Killias, M., Steketee, M., \& Gruszczynska, B. (2012). The many faces of youth crime: Contrasting theoretical perspectives across countries and cultures. New York: Springer. 